\title{
JAKARTA TOURISM: TRANSPORTATION ON SUPPORTING TOURISM, LIMITATIONS, AND OPPORTUNITIES TO INCREASE TOURISM
}

\author{
Devi Nurindah Sari ${ }^{1}$, Jeriansyah Kusaeni ${ }^{2}$, Keronica $^{3}$ \\ 1. STMT Trisakti, 2.STMT Trisakti, 3.STMT Trisakti \\ corresponding author : jeriansyah.kusaeni@gmail.com
}

\begin{abstract}
In the current era, tourism is no longer merely a desire, but it has become a necessity for almost everyone. Tourism activities can not be separated from the relationship with transportation facilities that support these activities. In this study, we would like to discuss how big the role of transportation in supporting tourism activities and increasing the growth of tourism in Jakarta along with the opportunities, supporting factors and obstacles in increasing the growth of tourism. We use a descriptive model derived from science-direct, the next we determine the important points we input into the article to support our discussion. In the identification, it is found that transportation plays a big role in the growth of tourism that also affects the economic growth of the surrounding communities and the area so that poverty declines. While the environment, human resources, security, facilities, the determinants of tourism productivity. To solve the existing problem, we create a policy opinion to be developed for development and enhancing competitiveness with other regions.
\end{abstract}

Keywords: transportation, tourism, economy, Jakarta, infrastructure

\section{Introduction}

Tourism at this time is an important industry in the economic field around the world, which has a direct impact on the enormous economic growth for the surrounding community and the country, not least Jakarta. (Ţîţu, Răulea, \& Ţîţu, 2016), (Sharpley, 2002). Transport plays a very crucial role in supporting tourism activities and enhancing the success of the tourism industry(Van Truong \& Shimizu, 2017)(Pengguna et al., 2016). (Van Truong \& Shimizu, 2017), pointed out several points that can increase the number of tourists, including: ease of access to reach the destination (i), the attraction of a forced destination is the condition of the place (ii), the accommodation structure, which connect inter-modal between locations to reach the location, so tourist is easier to reach (iii), facilities, availability such as hotels, restaurants, etc. (iv), the organization means that the party providing the tour must provide a lucrative offer (v), additional services, here emphasizing the surrounding community as an additional role to make the tourist feel safe and comfortable. Factors in transportation that can 
impact on accessibility to destination sites according to(Van Truong \& Shimizu, 2017), include: the quality of transport modes (i), transport conetivity networks (ii) affordable transport costs (iii), mobility, including the availability of travel frequencies (iv ), integrated transportation, ease of use of mode to location (v), transportation demand (vi), clarity of information on mode availability (vii), replacement mobility (viii), transportation management, means providing facilities and infrastructure meeting criteria (Simarmata \& Keke, 2017)(ix) land use factor (x), priority of travel activity (xi), inaccessible or isolated areas (xii). Therefore, accessibility must be improved for the success of the economy of tourist destinations.(G. Li, Li, Ju, \& Zhang, 2017), there are 5 keys that support sustainable transport, described in the following table.

Tabel 1. keys that support sustainable transport

\begin{tabular}{|c|c|}
\hline Key issues & Guiding principle \\
\hline $\begin{array}{l}\text { Harmony of transportation } \\
\text { and land-use }\end{array}$ & $\begin{array}{l}\text { Principle } 1 \text { - Access: People have the right to have } \\
\text { reasonable access to other people, places, goods and } \\
\text { services. } \\
\text { Principle } 2 \text { - Land and resource use: The transport system } \\
\text { should utilize land and natural resources efficiently while } \\
\text { ensuring the preservation of vital habitats and other } \\
\text { requirements for maintaining biodiversity. Internal } \\
\text { integration of transportation system principles }\end{array}$ \\
\hline $\begin{array}{l}\text { Internal integration of } \\
\text { transportation system }\end{array}$ & $\begin{array}{l}\text { Principle } 3-\text { Integrated planning: Planners and } \\
\text { implementers of the transport system have a responsibility } \\
\text { to apply an integrated approach to planning with a higher } \\
\text { emphasis on public transport, walking and cycling.. }\end{array}$ \\
\hline $\begin{array}{ll}\text { Coordination } & \text { of } \\
\text { transportation and nature }\end{array}$ & $\begin{array}{l}\text { Principle } 4 \text { - Pollution Prevention: The transport system } \\
\text { should be developed in such a way as to produce lower } \\
\text { emissions that threaten public health, global climate, } \\
\text { biodiversity and ecology. }\end{array}$ \\
\hline $\begin{array}{l}\text { Coordination of } \\
\text { transportation and society }\end{array}$ & $\begin{array}{l}\text { Principle } 5 \text { - Individual responsibility: All individuals have } \\
\text { a responsibility to make sustainable choices for their } \\
\text { movement between places by reducing resource } \\
\text { consumption so as to improve the natural environment. } \\
\text { Principle } 6 \text { - Health and safety: The transport system should } \\
\text { be designed and operated in such a way that it reduces the } \\
\text { social costs of using the system by protecting the health and } \\
\text { safety of everyone, and improving their quality of life. } \\
\text { Principle } 7 \text { - Higher cost accounting: Provision of transport } \\
\text { systems and operations should be based on full cost } \\
\text { accounting, which includes social, economic and } \\
\text { environmental costs, and makes the user pay a fair share of } \\
\text { costs based on the use of the facility. } \\
\text { Principle } 8 \text { - Equity: State providers and service providers } \\
\text { should maintain social, environmental, economic, } \\
\text { intergovernmental and intergenerational. }\end{array}$ \\
\hline
\end{tabular}


Tabel 2. Value of support factors on tourism based questionnaire.

\begin{tabular}{|c|c|c|c|c|c|c|c|c|c|}
\hline Statement & SS & $\mathrm{S}$ & $\mathrm{N}$ & TS & STS & Scores & $\mathrm{Y}$ & Result & Description \\
\hline $\begin{array}{ll}\text { The quality } & \text { of } \\
\text { transportation mode in } & \text { in } \\
\text { Jakarta is good } & \end{array}$ & 1 & 13 & 25 & 31 & 3 & 197 & 365 & 53.97 & Enough \\
\hline $\begin{array}{l}\text { transport connectivity } \\
\text { network in Jakarta has } \\
\text { been good in reaching } \\
\text { tourist destinations }\end{array}$ & 1 & 33 & 24 & 13 & 2 & 237 & 365 & 64.9 & Agree \\
\hline $\begin{array}{l}\text { transportation costs in } \\
\text { Jakarta are affordable }\end{array}$ & 11 & 43 & 21 & 25 & 1 & 279 & 365 & 76.4 & Agree \\
\hline $\begin{array}{l}\text { the availability of travel } \\
\text { frequency in Jakarta has } \\
\text { been good }\end{array}$ & 1 & 23 & 21 & 25 & 3 & 213 & 365 & 58.3 & Enough \\
\hline $\begin{array}{l}\text { integrated transportation, } \\
\text { easy to reach tourist } \\
\text { destinations in Jakarta }\end{array}$ & 8 & 29 & 23 & 10 & 3 & 248 & 365 & 67.9 & Agree \\
\hline $\begin{array}{l}\text { the availability of } \\
\text { information in the use of } \\
\text { transportation modes in } \\
\text { Jakarta is clear }\end{array}$ & 2 & 33 & 21 & 13 & 4 & 235 & 365 & 64.3 & Agree \\
\hline $\begin{array}{l}\text { replacement mobility in } \\
\text { Jakarta is well structured }\end{array}$ & 0 & 21 & 36 & 13 & 3 & 221 & 365 & 60.5 & Agree \\
\hline $\begin{array}{l}\text { the provision of facilities } \\
\text { and infrastructure in } \\
\text { Jakarta is in accordance } \\
\text { with the standards }\end{array}$ & 3 & 16 & 27 & 24 & 3 & 211 & 365 & 57.8 & enough \\
\hline $\begin{array}{l}\text { land use factor in Jakarta } \\
\text { for transportation is } \\
\text { good }\end{array}$ & 1 & 20 & 20 & 28 & 4 & 205 & 365 & 56.1 & enough \\
\hline $\begin{array}{l}\text { the priority of travel } \\
\text { activities in Jakarta has } \\
\text { been conducted in a } \\
\text { balanced manner } \\
\text { between business } \\
\text { activities and tourism }\end{array}$ & 1 & 12 & 37 & 21 & 2 & 208 & 365 & 56.9 & enough \\
\hline $\begin{array}{l}\text { there is still a tourist area } \\
\text { in Jakarta that can not be } \\
\text { accessed by } \\
\text { transportation }\end{array}$ & 11 & 31 & 15 & 14 & 2 & 254 & 365 & 69.5 & agree \\
\hline $\begin{array}{l}\text { demand for public } \\
\text { transportation in Jakarta } \\
\text { is high }\end{array}$ & 26 & 35 & 7 & 4 & 1 & 300 & 365 & 81 & agree \\
\hline $\begin{array}{l}\text { the condition of tourist } \\
\text { areas in Jakarta is } \\
\text { interesting to visit }\end{array}$ & 7 & 33 & 25 & 6 & 2 & 256 & 365 & 70.1 & agree \\
\hline $\begin{array}{l}\text { the operators (travel) to } \mathrm{pr} \\
\text { tempting holiday offeri } \\
\text { Jakarta }\end{array}$ & 4 & 13 & 35 & 15 & 6 & 213 & 365 & 58.35 & enough \\
\hline
\end{tabular}

The purpose of this paper is to see how big the role of transportation in tourism and what factors can support and hamper in improving tourism. So in the end produce a policy in the development of the supporting factors that 
are still lacking and minimalyze barriers that exist to make the supporting factors as well.

\section{Method}

A case study is a way to understand and know more about the issues discussed by extending knowledge through discussions that have been done before. according to Kumar (1999) describes the case study is one method of approach and social assessment through the process of analyzing a case of individuals with a thorough and complete in order to provide results of intensive analysis in researching existing social phenomena. a case study called kumar is a research approach that has more details in its analysis, which is often overlooked in other research methods

Herman V. Schulard, Tourism is a number of activities, especially in relation to the economy directly related to the entry of foreigners through traffic in a particular country, city and region, tourists who visit Indonesia, especially in DKI Jakarta most are tourists who come from China (china ), as long as January 2017 visitors from China are foreign tourists to Jakarta, about 13-15\%. in January 26,923 kunjngan (13.89), february reached 26,579 visits (14.03\%), March reached 29,155 visits (13.16\%) April reached 30,904 visits (14.26\%) and May reached 31,786 visits (15.09\%) . visits by foreign tourists to Jakarta through 3-door masu namely, Soekarno Hatta, Tanjung Priok, and halim perdanakusuma in May 2017 reached 210,595 visits, which means decreased by 2.82\% compared to April 2017 which amounted to 216,704 visits. but if viewed annually, an increase in visits in May 2017 to May 2016 at 9.00 . 
Grafik 1. Perkembangan Jumlah Kunjungan Wisman ke DKI Jakarta

Mei 2015 sd Mei 2017 (ribuan kunjungan)

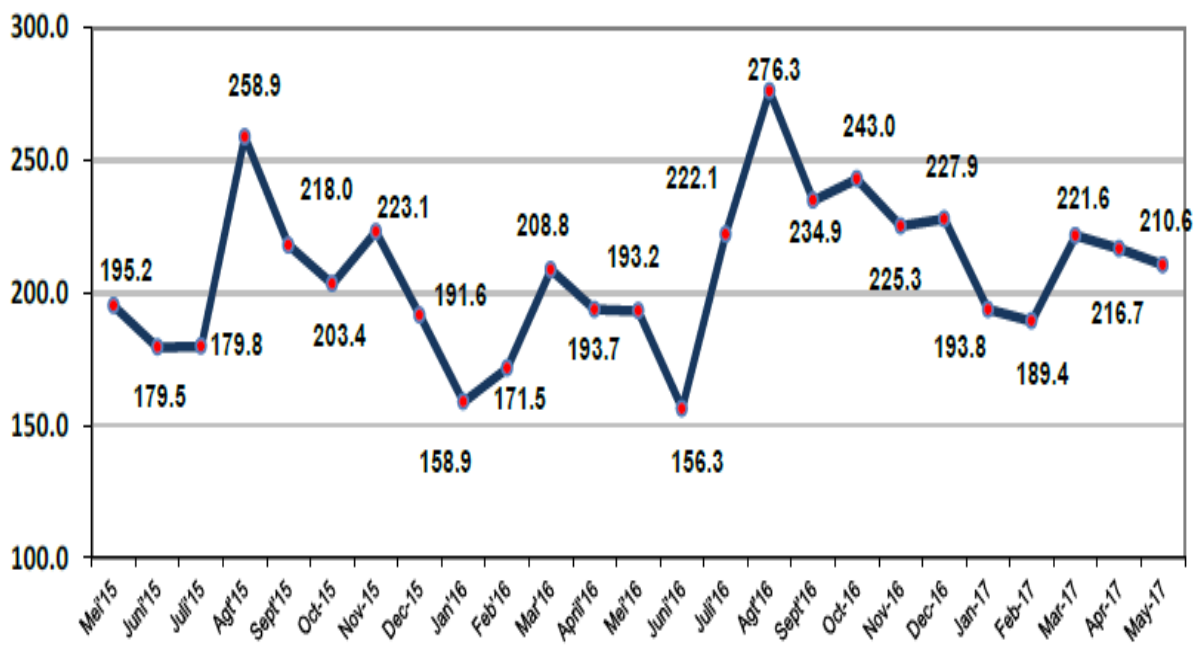

In its development, tourism also provides income for the State in the form of foreign exchange earnings. Foreign exchange revenue is influenced by the number and expenditure of foreign tourists in Indonesia. In developing national tourism, the increasing number of foreign tourists to Indonesia is pursued in line with the increasing number of foreign tourist expenditures in Indonesia, so that the country's income from tourism activities also increases. Based on data in 2015, the amount of foreign exchange revenue of foreign tourists has exceeded the target set of Rp. 163 trillion (11.9 billion USD) or the achievement of foreign exchange of $113.2 \%$ of the target set (Rp 144 trillion)

\section{Discussion and Result}

The role of transportation seems to allow people to easily access tourist destinations and to open new sights not previously attainable by transportation(Van Truong \& Shimizu, 2017). Transport is an important part of tourism development efforts (Prideaux, 2000). Tourists also benefit that can make them easier and convenient because of better transportation access (Gunn and Var 2002). Then, a good transportation system to the destination and destination can make the cost lower, easier to access to the sights because of the overall cost that can be saved(Van Truong \& Shimizu, 2017). 
In terms of the large number of requests that come to a tourist attraction, can be influenced by several factors that determine, such as; (1) supply-side factors, ie services, transportation, attractions, information, and promotions that can get people interested in visiting tourist attractions; (2) tour package prices, which include living expenses and travel expenses for tourists at tourist destinations; 3) tourist income, (4) currency, the rise and fall of a country's currency also affects international tourism, because when the currency goes down it can make tourism activity cheaper and increase the demand for the country, (5) trade volume, inter-state high, can improve the travel or business holidays; (6) information promotion activities of a tourist destination; and (7) other factors, such as booming events, political disturbances, and the similarity of tourist destination languages with their country of origin (uysal 1998). In research on tourism prediction.

It is clear that there is a close relationship between tourism and transportation accessibility factors, which certainly affects travel costs both in money and time spent on tourism, as well as in tourism supply and demand levels.Kweka (2004) studied the effects of transport on the economy and tourism on the assumption that a good transport infrastructure would reduce the amount of spent, marketing and distribution activities, thus increasing the number of tourists to a destination destination.

As mentioned earlier, good transportation and good infrastructure provision can have an impact on increasing the number of tourists to a destination destination, in this section we would like to discuss land use and transportation coordination strategies; governing spatial, urban planning, and traffic infrastructure in public transport preferences.

1) Determine major public transport corridors based on the city's planned urban functional division, taking into account the spatial layout of tourism resources, establishing several corridors connecting traffic within cities and between cities such as the construction of railways and toll roads that can also link areas tourist destinations.

2) Set up basic facilities around public transport corridors. An internal public transport center and an external transport hub will be located 
around the urban axis intensively to gain advantage of external and internal traffic connections with different traffic facilities or called intermodals. Meanwhile, major public transport and feeder will be arranged for the traveling of the residents and the integrated visitor. Here is an action that can be done.

- Establish transfer hubs, which include bus station and railway station infrastructure in inner city traffic corridors, major railway stations, and expand public transportation corridors; plotting a major arterial road to connect hubs with regional roads as the transport backbone actors in the urban axis, the hub also linking external traffic; therefore, it is necessary to build flyovers and underpasses and toll roads to reduce the density of vehicles within the city.

- Plan an airport which is also a hub transportation for other modes in order to facilitate people to make the transfer of transportation modes such as train facilities and public transport bus.(Ricardianto, Djajaputra, \& Martono, 2017)

- In the northern area of Jakarta, plan to build a corridor from the hub station to harbors that can take tourists to the islands of tourist destinations, while in the old city of Jakarta can be made vehicle restrictions policy to make the area around the destination more comfortable and more enjoyable.

3) Land planning with Transit Oriented Development mode. Urban land planning in accordance with the Oriented Develpoment Transit mode is the key to building sustainable transportation and providing a good transportation system to support tourism. On the other hand, should be accompanied by the construction of public service facilities along the main corridor of city center public transport, the facility includes cultural service centers, information service centers, office centers, open spaces, business centers, shopping centers, tourist business centers, and others etc. 
Integrated traffic system; tourist travel chains and integrated citizens to realize the use of tourism traffic and intensive urban sharing and traffic facilities.

- Tourist city traffic form.

The first form is the complexity of traffic users. In tourist cities, tourists and locals use the means of transport side by side in one space and one time. For the locals, their travel demand focuses on traffic flow, meaning they emphasize the type of economic transportation, safe and reliable. However, unlike the tourists who prefer the convenience of traffic both external and internal, this type of travel more emphasis on experience, enjoyment and entertainment so that makes traffic conditions in the city of tourist destinations to be complex and diverse. The second form is the fluctuation of traffic conditions. Because traffic in the tourism area can vary depending on the day and the holiday season, especially in the Jakarta area of natural tangibles such as on the beach and on a seasonal or holiday trip. The third form is to adjust to the model of tourism traffic. Travel and travel distribution modes can be piloted and intervened to be easily influenced by traffic demand and the layout of tourism facilities, making it possible for trip chain adjustments. Considering the form of traffic demand in tourist destination city, it is expected to avoid excessive infrastructure development and waste, meanwhile, action needs to be taken to realize facilities and services sharing between tourists and residents as far as possible. Efforts that can be done include analysis of travel patterns of tourists and residents, by integrating their travel chains through transportation hubs and knowing the demand for traffic infrastructure.

- Analyze the trip chains of tourists and residents

The first thing to do is to recognize or know the users or travel groups, in addition to urban residents and residents lokl, there 
are other groups of leisure travelers, cruise passengers, shopping tourists and so forth. Next determine the scale of the trips undertaken by each tourist who must have different scales, different interests, the sensitivity of traffic services and other factors.

The price factor also determines the level of tourism demand on an international scale(Darunanto, n.d.)(Van Truong \& Shimizu, 2017)(Prideaux, 2000), the price of tourism used in the demand model as the main determinant is common in econometric tourism demand studies. According to(K. X. Li, Jin, \& Shi, 2017) tour prices consist of transportation costs plus living costs. The cost of living has two components; ie the price of services and goods in the destination country and the exchange rate. The exchange rate, another part of the cost of living indicator, was also investigated by(K. X. Li et al., 2017). When a country's currency has a low or low value, its price is more competitive and that is why the demand for tourism travel to the country is increasing. Conversely, if the value of a country's currency increases, then the competitiveness of prices decreased resulting in reduced tourism interest to the country (De Vita, 2014). Transportation costs are also part of the tour price. Since some of the total travel costs come from transportation costs, the increase in transportation costs can have a negative effect with the declining tourism flow in the next period(Hobson \& Dietrich, 1995);(Divisekera, 2003). Mileage, oil prices and tariffs are part of transportation costs(Durbarry, 2004)(Kulendran \& Witt, 2001)

\section{Conclusion}

To undertake sustainable development in integrated traffic planning in a tourist destination city, the main issues are the coordination of land use and transportation, transportation and natural coordination, traffic facilities, internal integration of transportation systems, humane considerations, and transport and community coordination(Kadarisman, Gunawan, \& Ismiyati, 2017). Based on several factors above, planning and design should also be 
made in accordance with local conditions in a friendly and accurate. Therefore, the government must create a good and viable traffic foundation to support sustainable development.

And also, the fact that tourism is required to be quality has become one of the issues of international tourism policy in the future as the rapid growth of the tourism industry, which is one of the main economic sectors in 2000 and beyond. Organizations at all levels, such as entrepreneurship, regional, national, and international have shown concern for quality tourism. However, the increasing number of tourists who are not satisfied with tourism in Jakarta shows that the business initiatives that have been done so far aim to improve the quality of tourism is still not considered effective. This refers to questions surrounding the reasons for quality problems in tourism at the moment, and opens the possibility of efforts to improve quality in the local tourism industry

Although experience-based data or facts about the relationship between economic growth and tourism are not yet convincing in this case the international tourism scope, but in the local scope is considered an important impetus for improving national and regional economies. This is because tourism plays an important role in opening employment opportunities around tourist destinations such as opening a trade business, providing lodging facilities, and so on, can also improve the infrastructure with the entry of foreign exchange countries from the tourists. After a systematic review, tourism encouragement is examined by evaluating its contribution to poverty reduction, measuring tourism productivity and tourism efficiency, impacting its economy and assessing external economic factors that could affect tourism.

The government can play an important role in promoting the economic drive of tourism. By balancing its social, environmental, and political impacts and economic impacts, the government can efficiently guide investment in tourism. With the right job training project and with the help of redistribution policy, can achieve the goal to alleviate poverty. In addition, there is the potential for governments to eliminate the adverse 
effects of external economic factors by providing pre-employment training, offering subsidies to the tourism industry, promoting affordable tourist markets, encouraging the adoption of new technologies, enhancing tourism competitiveness, and also improving tourism efficiency.

Accessibility factors also have an impact on tourism improvements such as infrastructure improvements, provision of information, and affordable travel costs should be considered in tourism development. There is a problem in managing accessibility factors that is difficult to integrate components that are in accessibility. At present there have been many studies emphasizing the role of transport in tourism in non-technical terms, but it is still important to make decisions in accordance with relevant circumstances and based on existing experience studies, so as to create and develop effective transport policies to support the tourism industry.

This study can be a powerful tool for evaluating the effectiveness of transportation projects.

Accessible tourism can also be a great opportunity for tourism operators and can bring economic benefits within both the macro and micro-economic scope. From a micro perspective, the problem of low tourism demand can be attributed to factors; the possibility of the quality offered is low and needs to be developed; allowing for higher profits. From the macro side, its superiority is related to developing the national tourism industry thus creating employment and income revenue from abroad. But there are still many restrictions that can hamper the development of accessibility that is easily accessible in Jakarta. Among the former, the inability to build the infrastructure of local facilities and adequate accommodation facilities. Next, the capability of human resources, the travel operator in this case is the staff is still low in terms of training. 


\section{References}

Darunanto, D. (n.d.). Layanan Terhadap Kepuasan Pelanggan Pt . Dms Tour and Travel, 201-219.

De Vita, G. (2014). The long-run impact of exchange rate regimes on international tourism flows. Tourism Management, 45, 226-233. https://doi.org/10.1016/j.tourman.2014.05.001

Divisekera, S. (2003). A model of demand for international tourism. Annals of Tourism Research, 30(1), 31-49. https://doi.org/10.1016/S01607383(02)00029-4

Durbarry, R. (2004). Tourism and economic growth: the case of, 10(4), 389-401.

Hobson, J. S. P., \& Dietrich, U. C. (1995). Tourism, Health and Quality of Life: Journal of Travel \& Tourism Marketing,3(4), 21-38. https://doi.org/10.1300/J073v03n04

Kadarisman, M., Gunawan, A., \& Ismiyati, I. (2017). Kebijakan Manajemen Transportasi Darat Dan Dampaknya Terhadap Perekonomian Masyarakat Di Kota Depok. Jurnal Manajemen Transportasi Dan Logistik, $3(1), \quad 41$. https://doi.org/10.25292/j.mtl.v3i1.140

Kulendran, N., \& Witt, S. F. (2001). Cointegration versus least squares regression. Annals of Tourism Research, 28(2), 291-311. https://doi.org/10.1016/S0160-7383(00)00031-1

Lamb, Barbara, and Sally Davidson. 1996. "Tourism and Transportation in Ontario, Canada: A Vital Link." In Practicing Responsible Tourism: International Case Studies in Tourism Planning, Policy and Development. John Wiley and Sons.

Li, G., Li, B., Ju, M., \& Zhang, Z. (2017). Discussion on Integrated Traffic Planning(ITP) of New Tourism Town upon Sustainable Development and Livable Request. Transportation Research Procedia, 25, 34023415. https://doi.org/10.1016/j.trpro.2017.05.231

Li, K. X., Jin, M., \& Shi, W. (2017). Tourism as an important impetus to promoting economic growth: A critical review. Tourism Management Perspectives, (April 2016), 0-1. https://doi.org/10.1016/j.tmp.2017.10.002

Pengguna, K., Transportasi, J., Loyalitas, U. M., Saribanon, E., Tinggi, S., Trisakti, M. T., ... Trisakti, T. (2016). Kepuasan Pengguna Jasa Transportasi Untuk Meningkatkan Loyalitas the Satisfaction of Transportation'S Customers To Enchance Loyalty. Jurnal Manajemen Transportasi \& Logistik, 3(3), 317-326.

Prideaux, B. (2000). The role of the transport system in destination development. Tourism Management, 21(1), 53-63. https://doi.org/10.1016/S0261-5177(99)00079-5

Ricardianto, I. P., Djajaputra, D. G., \& Martono, P. D. (2017). Air Transport and Tourism in Indonesia. IOSR Journal of Applied Chemistry, 10(5), 01-19. https://doi.org/10.9790/5736-1005010119

Sharpley, R. (2002). The challenges of economic diversification through tourism: the case of Abu Dhabi. International Journal of Tourism 
Research, 4(3), 221-235. https://doi.org/10.1002/jtr.378

Simarmata, J., \& Keke, Y. (2017). The Influence of Travel Agent, Infrastructure and Accommodation on Tourist Satisfaction, 28(Ictgtd 2016), 281-283. https://doi.org/10.2991/ictgtd-16.2017.55

Ţîţu, M. A., Răulea, A. S., \& Ţîţu, Ş. (2016). Measuring Service Quality in Tourism Industry. Procedia - Social and Behavioral Sciences, 221, 294-301. https://doi.org/10.1016/j.sbspro.2016.05.118

Van Truong, N., \& Shimizu, T. (2017). The effect of transportation on tourism promotion: Literature review on application of the Computable General Equilibrium (CGE) Model. Transportation Research Procedia, 25, 3100-3119. https://doi.org/10.1016/j.trpro.2017.05.336

https://books.google.co.jp/books?hl=en \&lr=\&id=fntlPooU2wUC\&oi=fnd\& pg=PA79\&dq=The+determinants+of+tourism+demand:+a+theoretical + perspective\&ots=U9V_P6YDKE\&sig=CGUYexxb5IpcUlh_MnBiCnFnic (uysal)

https://books.google.co.jp/books?hl=en\&lr=\&id=6S6e44VhObMC\&oi=fnd \&pg=PR9\&ots=RdXLlmvtP0\&sig=vZhwWtM1YdJbVr5Wy_odBK6F O64\#v=onepage \&q\&f=false (gunn)

http://www.safarilands.org/docs/tourism-and-the-economy-oftanzania2004.pdf. (kweka) 